https://doi.org/10.19195/0137-1134.120.26

\author{
WOJCIECH SZYDLO \\ ORCID: 0000-0003-3987-9318 \\ Uniwersytet Wrocławski \\ Instytut Prawa Cywilnego \\ Zakład Prawa Cywilnego i Prawa Międzynarodowego Prywatnego
}

\title{
ZASADY ORGANIZACJI I DZIAŁANIA ORGANU EUROPEJSKICH REGULATORÓW ŁĄCZNOŚCI ELEKTRONICZNEJ. WYBRANE ASPEKTY PORZĄDKU INSTYTUCJONALNEGO W SEKTORZE ŁĄCZNOŚCI ELEKTRONICZNEJ*
}

\begin{abstract}
Abstrakt: Podstawowym zadaniem Organu Europejskich Regulatorów Łączności Elektronicznej (Body of European Regulators in Electronic Communications - BEREC) jest doradzanie Komisji Europejskiej oraz organom regulacyjnym krajów członkowskich wchodzącym w jego skład, a ponadto wspieranie Parlamentu Europejskiego i Rady w sprawach dotyczących stosowania unijnych ram regulacyjnych dotyczących łączności elektronicznej. Jego działalność pozwala zapewnić uczciwą konkurencję i spójność regulacji na rynku wewnętrznym w dziedzinie łączności elektronicznej, z korzyścią dla europejskich konsumentów. Obecnie BEREC ma status niezależnego organu regulacyjnego, skupiającego w swej strukturze decyzyjnej krajowe organy regulacyjne, czerpiąc w swojej działalności z ich wiedzy eksperckiej i doświadczeń regulacyjnych. Jakkolwiek regulacja w sektorze telekomunikacyjnym w dalszym ciągu leży w gestii krajowych organów regulacyjnych, ponieważ to one są najbliżej rynków, które mogą lepiej regulować.

W artykule zostały omówione zasady organizacji oraz funkcjonowania Organu Europejskich Regulatorów Łączności Elektronicznej w kontekście zgodności przepisów regulujących jego działalność z zasadami dobrego zarządzania jako wartościami administracyjnymi i organizacyjnymi, które powinny determinować sposób korzystania przez instytucje unijne z uprawnień udzielonych im przez obywateli. W tekście zwrócono także uwagę na planowaną kompleksową reformę regulacji w sektorze łączności telekomunikacyjnej jako niezwykle ambitny projekt w ramach strategii Jednolitego Rynku Cyfrowego.
\end{abstract}

Słowa kluczowe: Organ Europejskich Regulatorów Łączności Elektronicznej, BEREC, sektor łączności elektronicznej, Urząd Komunikacji Elektronicznej, regulacja sektorów infrastrukturalnych

* Artykuł został przygotowany w ramach badań prowadzonych w projekcie badawczym Narodowego Centrum Nauki finansowanym na podstawie decyzji numer DEC-2013/08/A/ HS5/00642. 


\section{POWSTANIE ORGANU EUROPEJSKICH REGULATORÓW ŁĄCZNOŚCI ELEKTRONICZNEJ JAKO PRZEJAW INSTYTUCJONALNYCH ZMIAN W SEKTORZE ŁĄCZNOŚCI ELEKTRONICZNEJ}

Widoczne braki i niedociągnięcia regulacji unijnej w sektorze łączności elektronicznej ${ }^{1}$ stały się powodem podjęcia dyskusji nad zmianami ${ }^{2}$, które zaowocowały uchwaleniem rozporządzenia Parlamentu Europejskiego i Rady (WE) nr 1211/2009 z dnia 25 listopada 2009 roku ustanawiającego Organ Europejskich Regulatorów Łączności Elektronicznej (BEREC) oraz Urząd ${ }^{3}$ (dalej: rozporządzenie). Dotychczas istniejące rozwiązania instytucjonalne w sektorze łączności elektronicznej, powierzające regulację rynków niezależnym krajowym organom regulacyjnym (dalej: KOR), których zadaniem było w szczególności sprawowanie bieżącego nadzoru nad rynkami telekomunikacyjnymi w poszczególnych krajach członkowskich, nie przynosiły pożądanych skutków zwłaszcza w kwestii szybkości, skuteczności i jednolitości regulacji rynku (wewnętrznego), jak też odpowiedzialności i transparentności organów regulacyjnych. Stan ten dowodził, że alokacja zadań regulacyjnych w sektorze łączności elektronicznej w UE powinna skupiać się w jednej (centralnej) instytucji, która koordynowałaby podejście unijne do świadczenia usług o potencjale ogólnoeuropejskim lub wymiarze międzynarodowym. Taka koordynacja rozwiązań regulacyjnych wydawała się niezbędna do zapewnienia pełnego wykorzystania rynku europejskiego przez europejskie przedsiębiorstwa, tak by Europa mogła skutecznie konkurować w skali globalnej ${ }^{4}$.

W toku prac i dyskusji ostatecznie nie zdecydowano się na centralizację kompetencji regulacyjnych na poziomie europejskim przez utworzenie Europejskiego Urzędu Regulacyjnego ${ }^{5}$, a na utworzenie Organu Europejskich Regulatorów Łącz-

1 Zob. dyrektywa ramowa 2002/21/WE (Dz.U. L 108 z 24.04.2002 r., s. 33); dyrektywa o dostępie 2002/19/WE (Dz.U. L 108 z 24.04.2002 r., s. 7); dyrektywa w sprawie zezwoleń 2002/20/WE (Dz.U. L 108 z 24.04.2002 r., s. 21); dyrektywa o usłudze powszechnej 2002/22/WE (Dz.U. L 108 z 24.04.2002 r., s. 51) i dyrektywa o prywatności i łączności elektronicznej 2002/58/WE (Dz.U. L 201 z 31.07.2002 r., s. 37).

2 Zob. m.in. Komunikat Komisji do Rady, Parlamentu Europejskiego, Europejskiego Komitetu Ekonomiczno-Społecznego i Komitetu Regionów z dnia 26 czerwca 2006 roku w sprawie przeglądu uregulowań prawnych UE w zakresie sieci i usług łączności elektronicznej \{SEC (2006) 816\}\{SEC (2006) 817\} COM (2006) 334; wniosek rozporządzenia Parlamentu Europejskiego i Rady ustanawiające Europejski Urząd ds. Rynku Łączności Elektronicznej \{SEC (2007) 1472\} \{SEC (2007) 1473\} COM (2007) 699.

${ }^{3}$ Dz.U. L 337 z 18.12.2009 r., s. 1.

${ }^{4}$ Szerzej zob. J.T. Lang, The duties of cooperation of national authorities and courts under Article 10 E.C.: Two more reflections, „European Law Review” 26, 2001, s. 84; S. Lavrijssen-Heijmans, L. Hancher, European regulators in the network sectors: Revolution or evolution?, „TILEC Discussion Paper” 24, 2008, s. 10-12.

${ }^{5}$ Szerzej zob. F. Kamiński, Nowelizacja pakietu regulacyjnego dla rynku komunikacji elektronicznej Unii Europejskiej - Organ Europejskich Regulatorów Łaczności Elektronicznej, „Biuletyn Informacyjny Instytutu Łączności” 2009, nr 1, s. 3-14. 
ności Elektronicznej (dalej: BEREC) jako specjalnej instytucji skupiającej w swej strukturze decyzyjnej KOR, powołanej w celu zapewnienia wiedzy i doradztwa głównie o charakterze technicznym, potrzebnej do analizy rynku i wydawania zezwoleń na świadczenie usług o potencjale ogólnoeuropejskim. Zadecydowano również, że wsparcie administracyjne i merytoryczne Organowi Europejskich Regulatorów Łączności Elektronicznej zapewni Urząd Organu Europejskich Regulatorów Łączności Elektronicznej (dalej: Urząd BEREC), który przyjął postać europejskiej agencji ${ }^{6}$, stając się tym samym odrębnym i niezależnym podmiotem, mieszczącym się poza strukturą organizacyjną Komisji Europejskiej (dalej: Komisja) ${ }^{7}$.

BEREC uzyskał status niezależnego organu, skupiającego w swej strukturze decyzyjnej KOR wszystkich krajów członkowskich UE, korzystając z ich wiedzy eksperckiej i doświadczeń regulacyjnych. BEREC przejął tym samym rolę odgrywaną przez ERG, wraz z równoczesnym uzyskaniem nadzoru nad środkami nakładanymi przez KOR, jednakże z zastrzeżeniem doradczej jego roli w tym zakresie, która byłaby związana również z ulepszaniem procedur analizy rynków międzynarodowych i tworzeniem nowych procedur unijnych dotyczących autoryzacji i regulacji usług o potencjale ogólnoeuropejskim. W swym założeniu BEREC funkcjonuje jako forum współpracy KOR z Komisją w ramach wykonywania swoich zadań z zakresu ram regulacyjnych UE. Służy doświadczeniem i wiedzą specjalistyczną, a z racji swej niezależności, jakości doradztwa i przekazywanych informacji, przejrzystości swoich procedur i metod działania, a także dbałości w wykonywaniu powierzonych mu zadań wzbudza spore zaufanie w opinii uczestników rynku. Jego rolą jest wspomaganie KOR oraz Komisji, z zastrzeżeniem, że nie może zastępować ich funkcji ani powielać prowadzonych już prac. BEREC swoim działaniem powinien przyczyniać się także do rozwijania współpracy KOR z Komisją, aby zapewniać spójne stosowanie we wszystkich państwach członkowskich ram regulacyjnych UE dla sieci i usług łączności elektronicznej, a tym samym przyczynić się do rozwoju i lepszego funkcjonowania rynku wewnętrznego. Jednocześnie jednak KOR i Komisja powinny uwzględniać wszelkie opinie, zalecenia, wytyczne, rady lub najlepsze praktyki regulacyjne

${ }^{6}$ Szerzej zob. G. Majone, The agency model: The growth of regulation and regulatory institutions in the European Union, „EIPASCOPE” 6, 1997, s. 9; E. Chiti, The emergence of a community administration: the case of European agencies, „Common Market Law Review” 37, 2000, s. 309; E. Vos, Reforming the European Commission: What role to play for EU agencies?, „Common Market Law Review" 37, 2000, s. 1113; M. Everson, Independent agencies: Hierarchy beaters?, „European Law Journal” 2, 1995, s. 180; X.A. Yataganas, Delegation of regulatory authority in the European Union - The relevance of the American model of independent agencies, „Jean Monnet Working Paper" 3, 2001, nr 1, s. 4 n.; D. Geradin, N. Petit, The development of agencies at EU and national levels: Conceptual analysis and proposals for reform, „Working Paper Series” 2004, s. 35 n., http://ssrn.com/abstract=489722 (dostęp: 3.10.2018).

7 BEREC został utworzony rozporządzeniem Parlamentu Europejskiego i Rady (WE) nr 1211/2009 z dnia 25 listopada 2009 roku ustanawiającym Organ Europejskich Regulatorów Łączności Elektronicznej (BEREC) oraz Urząd (Dz.U. L 337 z 18.12.2009 r., s. 1-10) (dalej: rozporządzenie). 
przyjęte przez BEREC. BEREC powinien dodatkowo służyć jako podmiot dostarczający przemyśleń, dyskusji i rad dla Parlamentu Europejskiego, Rady Europejskiej i Komisji, zarówno na ich wniosek, jak i z własnej inicjatywy. W stosownych przypadkach BEREC może także, przed wydaniem swojej opinii dla Komisji, skonsultować się z odpowiednimi krajowymi organami ds. ochrony konkurencji ${ }^{8}$. Każde ze swoich działań BEREC powinien podejmować jednak w sposób niezależny, bezstronny i przejrzysty9 .

BEREC ma własny organ zarządzający. Jest nim Rada Organów Regulacyjnych, do której kompetencji należy wykonywanie określonych w art. 3 rozporządzenia zadań BEREC i podejmowanie wszystkich decyzji dotyczących wypełniania jego obowiązków. Złożona jest $\mathrm{z}$ jednego przedstawiciela $\mathrm{z}$ każdego państwa członkowskiego, będącego zwierzchnikiem lub wyższym rangą mianowanym przedstawicielem KOR utworzonego w każdym państwie członkowskim, odpowiedzialnym przede wszystkim za nadzór nad bieżącym funkcjonowaniem rynków sieci i usług łączności elektronicznej. KOR dodatkowo nominują do Rady Organów Regulacyjnych po jednym zastępcy z każdego państwa członkowskiego, Komisja zaś ma możliwość uczestniczenia w jej pracach, jednak wyłącznie jako obserwator. Rada Organów Regulacyjnych obraduje na swoich plenarnych posiedzeniach, a na każde z nich musi zostać zaproszony przedstawiciel Komisji. Prace BEREC mogą odbywać się ponadto w eksperckich grupach roboczych (zob. art. 4 i 5 rozporządzenia).

Wsparciem administracyjnym i merytorycznym dla BEREC jest wspomniany już Urząd BEREC, usytuowany już jednak jako agencja unijna. Realizuje on, poza obsługą administracyjną BEREC, zadania i kompetencje opiniodawcze oraz doradcze, wówczas gdy te rozstrzygające leżą po stronie sieci zdecentralizowanej, a więc samego BEREC. W jego skład wchodzi Dyrektor Zarządzający, powoływany na trzyletnią kadencję do kierowania pracami Urzędu, oraz Komitet Zarządzający, złożony z po jednym członku z każdego kraju członkowskiego, plus jeden członek reprezentujący Komisję (zob. art. 6-9 rozporządzenia).

W BEREC najważniejszą rolę odgrywają zatem przedstawiciele KOR. Dlatego uzasadnione jest twierdzenie, że w sektorze telekomunikacyjnym mamy do czynienia z zastosowaniem modelu instytucjonalnego mieszanego, w ramach którego

${ }^{8}$ Należy wskazać, że w sektorach sieciowych organy ochrony konkurencji oraz organy regulacyjne występują paralelnie. Pomiędzy nimi powinna występować daleko idąca i normatywnie ukształtowana współpraca i współdziałanie. W literaturze postuluje się również rozwiązanie, pozbawione chyba jednak głębszych merytorycznych racji, aby zrezygnować w ramach sektorów sieciowych z instytucjonalnej odrębności pomiędzy organami ochrony konkurencji a organami regulacyjnymi i powierzyć zadania i kompetencje każdej z tych dwóch grup organów wyłącznie jednej z nich. Zdania co do zasadności każdego z tych rozwiązań są podzielone i mają tyle samo zwolenników co przeciwników. Na temat relacji pomiędzy organami regulacji a organami konkurencji w zakresie sektorów sieciowych zob. M. Szydło, Prawo konkurencji a regulacja sektorowa, Warszawa 2010, s. 269-309; M.B. Nenova, EC Electronic Communications and Competition Law, London 2007, s. $121-122$.

9 Podstawowe zadania BEREC wskazuje art. 3 rozporządzenia. 
równocześnie istnieją zarówno organ (lub organy) unijne, jak i organy krajowe, pomiędzy którymi zachodzi określona relacja prawna, nazywana mianem sieci. BEREC jest jednak swego rodzaju zdecentralizowaną siecią KOR, której członkowie nie stanowią części jakiejkolwiek instytucji centralnej $\mathrm{UE}^{10}$. Tego rodzaju sieć łączy organ (lub organy) unijne oraz KOR poszczególnych krajów członkowskich (które zachowują swoje uprawnienia regulacyjne, jak choćby polski Urząd Komunikacji Elektronicznej), a jej uczestnicy nie tworzą odrębnej struktury organizacyjnej, nie stając się odrębnym podmiotem prawa (na przykład osobą prawną). Niemniej jednak BEREC, nie będąc co prawda odrębnym, samodzielnym podmiotem prawa, jest określoną jednostką organizacyjną, w sensie sformalizowanej struktury, która tworzy pewne formalne reguły określające zasady jej funkcjonowania, ma własne kompetencje, skupiając w swoich ramach dodatkowe, ściślej określone jednostki organizacyjne ${ }^{11}$. Mimo że mamy zatem do czynienia $\mathrm{z}$ dużym stopniem sformalizowania i ustrukturalizowania BEREC, nie możemy nazwać go ciałem stricte unijnym, lecz ciałem funkcjonującym pomiędzy szczeblem unijnym a krajowym ${ }^{12}$. Rozstrzygnięcia dotyczące funkcjonowania sektora telekomunikacyjnego w UE podejmowane są tym samym przez strukturę usytuowaną $\mathrm{w}$ zawieszeniu pomiędzy szczeblem unijnym a krajowym. Podejmując je, BEREC, jak każda sieć zdecentralizowanych organów regulacyjnych, musi przestrzegać wielu kluczowych zasad dobrego zarządzania (odpowiedzialności, przejrzystości, udziału i prawnej ochrony interesariuszy), których realizacja bywa jednak często krytykowana z uwagi na brak jasnego określenia zasad prawnej i politycznej odpowiedzialności oraz rozliczalności za podejmowane działania, ale i dostatecznego zagwarantowania uprawnień proceduralnych dla przedsiębiorców, których dotyczą rozstrzygnięcia podejmowane przez zdecentralizowane sieci organów ${ }^{13}$.

\section{ZASADY DOBREGO ZARZĄDZANIA W DZIAŁALNOŚCI BEREC}

Powszechny odbiór BEREC jest w znacznej mierze zależny od tego, jak stosuje się on w swojej działalności do zasad dobrego zarządzania, których realizacja jest jednym z kluczowych mechanizmów odnoszących się do oceny organizacji i funkcjonowania instytucji UE. Zasady dobrego zarządzania są postrzegane w UE jako wartości administracyjne (i organizacyjne), które determinują sposób, w jaki UE korzysta z uprawnień udzielonych jej przez obywateli. W zamierzeniu realizacja tych zasad powinna prowadzić do lepszego wykorzystania uprawnień, które z kolei powinny ściślej połączyć UE z jej obywatelami i spowodować skutecz-

10 Szerzej zob. M. Szydło, op. cit., s. 276 n.

11 Podobną strukturę ma specjalny Komitet Doradczy ds. Praktyk Ograniczających Konkurencję i Pozycji Dominujących.

12 M. Szydło, op. cit., s. 302-303.

13 Szerzej zob. ibidem, s. 277, 305; S. Lavrijssen-Heijmans, L. Hancher, op. cit., s. 13. 
niejsze prowadzenie polityki ${ }^{14}$. Dobre zarządzanie jest bez wątpienia kluczowym czynnikiem decydującym o powodzeniu lub niepowodzeniu wszystkich organów regulacyjnych, na poziomie zarówno europejskim, jak i krajowym ${ }^{15}$. Obecnie możemy wymienić cztery podstawowe zasady dobrego rządzenia: (1) odpowiedzialność, (2) przejrzystość, (3) udział interesariuszy i (4) ich ochrona prawna, które mogą być punktem odniesienia w poniższych rozważaniach w kontekście działalności BEREC.

W odniesieniu do ponoszenia odpowiedzialności przez BEREC należy wskazać, że to, iż jest on niezależną instytucją, położoną poza obrębem Komisji ${ }^{16}$, nie służy jako pretekst do zwolnienia go z wszelkich form kontroli. Poddany jest wszakże kontroli zewnętrznej, jak ocena i przegląd działalności (dokonywane przez Komisję), kontrola budżetowa i finansowa (w tym audyt przeprowadzany między innymi przez Księgowego Komisji i Trybunału Obrachunkowego oraz Europejski Urząd ds. Zwalczania Nadużyć Finansowych — OLAF), kontrola polityczna (sprawowana przez Parlament Europejski, Radę i Komisję ${ }^{17}$ ), kontrola administracyjna Europejskiego Rzecznika Praw Obywatelskich oraz kontrola sądowa (sprawowana przez sąd pierwszej instancji — SPI i Trybunał Sprawiedliwości Unii Europejskiej — TSUE) ${ }^{18}$.

W celu zapewnienia pożądanego poziomu przejrzystości instytucje UE (jak też organy regulacyjne) powinny stosować jasne i proste procedury oraz zachowywać otwartość z interesariuszami na temat swych celów, metod i danych, z zastrzeżeniem wymogów poufności, a informacje o wynikach procesów regulacyjnych powinny być podawane do publicznej wiadomości, w szczególności poprzez obowiązek publikacji decyzji regulacyjnych ${ }^{19}$. W wypadku BEREC prawodawca europejski nie tylko wyraźnie stwierdza, że ma on wykonywać swoje działania z zachowaniem wysokiego stopnia przejrzystości, lecz także powinien starać się

14 Biała księga Komisji w sprawie sprawowania rządów w Europie, COM (2001) 428; ogólny zarys w: Good Governance in Europe's Integrated Market, red. C. Joerges, R. Dehousse, Oxford 2002.

15 Zob. D. Geradin, N. Petit, op. cit., s. 6.

${ }^{16}$ Należy tu przypomnieć, że organy BEREC działają niezależnie i nie przyjmują żadnych instrukcji od żadnego państwa członkowskiego, KOR, Komisji ani jakiejkolwiek strony trzeciej.

17 Szerzej zob. np. rezolucja Parlamentu Europejskiego z dnia 10 grudnia 2013 roku, zawierająca opinię na temat sprawozdania z oceny BEREC i Urzędu (2013/2053(INI)), P7_TA(2013)0536; sprawozdanie dotyczące sprawozdania finansowego Urzędu Organu Europejskich Regulatorów Łączności Elektronicznej za rok budżetowy 2016 wraz z odpowiedziami Urzędu, https://www.eca. europa.eu/Lists/ECADocuments/BEREC_2016/BEREC_2016_PL.pdf (dostęp: 14.09.2019).

18 Opisany system rozliczania BEREC z odpowiedzialności ma pewne luki, jak choćby brak kontroli politycznej sprawowanej przez parlamenty krajowe, które nie mogą wezwać komisarza czy dyrektora agencji europejskiej do przedstawienia wyjaśnień w sprawie sposobu realizacji uprawnień przekazanych przez urzędy krajowe; szerzej zob. S. Lavrijssen-Heijmans, L. Hancher, op. cit., s. 23; M. Szydło, Krajowy parlament jako regulator sektorów sieciowych, Warszawa 2013, passim; Parlament jako instytucjonalny uczestnik sektorów sieciowych, red. M. Szydło, W. Szydło, Wrocław 2014, passim.

19 Zob. D. Geradin, N. Petit, op. cit., s. 27. 
gwarantować odpowiedni poziom przejrzystości, spełniając bardziej szczegółowe wymagania, takie jak: jawny regulamin, na podstawie którego podejmuje decyzje; szczególne przepisy (środki praktyczne) w sprawie prawa dostępu do dokumentów BEREC; roczne sprawozdanie z działalności BEREC, które należy podać do wiadomości publicznej; upublicznianie wyników każdej procedury konsultacyjnej, wydawanych decyzji oraz dokumentów (w formie metodyk i specjalnych wytycznych), które na bieżąco wyjaśniają sposób, w jaki BEREC realizuje czy zamierza realizować swoje uprawnienia wobec zainteresowanych krajowych organów regulacyjnych i przedsiębiorstw; respektowanie wymogów dotyczących poufności zgodnie $\mathrm{z}$ art. $287 \mathrm{WE}$ i ochrona osób $\mathrm{w}$ trakcie przetwarzania ich danych osobowych ${ }^{20}$. Uzasadniony jest tym samym pogląd, że chociaż przejrzystość nie zastępuje odpowiedzialności (i luk w niej istniejących), to może wspomagać odpowiedzialność, w tym sensie, że politycy i interesariusze są wówczas w stanie monitorować działalność agencji UE i wymagać od nich wyjaśnieńn ${ }^{21}$.

Udział interesariuszy w podejmowaniu decyzji regulacyjnych przynosi wiele korzyści. Gwarantuje dobrą ocenę praktycznych skutków decyzji regulacyjnych oraz sprawia, że decyzje regulacyjne są lepiej przyjmowane przez podlegające im strony ${ }^{22}$. Dlatego BEREC w uzasadnionych przypadkach przed spełnieniem swych obowiązków powinien konsultować się z zainteresowanymi stronami i dać im możliwość wyrażania swoich uwag w rozsądnym terminie oraz podawać do wiadomości publicznej wyniki procedury konsultacji.

Poza wskazanymi zabezpieczeniami proceduralnymi gwarantującymi interesariuszom przejrzystość i udział ważne jest dla nich również posiadanie dostępu do odpowiedniej ochrony prawnej przed działaniami podejmowanymi przez UE, które godzą $\mathrm{w}$ ich interesy ${ }^{23}$. Co prawda rozporządzenie ustanawiające BEREC nie przewiduje możliwości odwoływania się do SPI lub TSUE przeciw decyzjom podejmowanym przez BEREC, ale ochrona prawna w postaci kontroli sądowej przed sądami europejskimi jest zagwarantowana klasycznymi zasadami traktatu WE, regulującymi postępowanie o stwierdzenie nieważności (por. art. $230 \mathrm{WE}$ ).

\section{PLANOWANE PRZEKSZTAŁCENIA INSTYTUCJONALNE W ORGANIZACJI I FUNKCJONOWANIU BEREC}

W maju 2015 roku w swoim komunikacie „Strategia jednolitego rynku cyfrowego dla Europy" Komisja Europejska zapowiedziała gruntowną i kompleksową

20 Zob. rozporządzenie (WE) nr 45/2001 Parlamentu Europejskiego i Rady z dnia 18 grudnia 2000 roku o ochronie osób fizycznych w związku z przetwarzaniem danych osobowych przez instytucje i organy wspólnotowe i o swobodnym przepływie takich danych (Dz.U. L 8 z 12.01.2001 r., s. 1).

21 S. Lavrijssen-Heijmans, L. Hancher, op. cit., s. 14.

22 Zob. D. Geradin, N. Petit, op. cit., s. 57.

23 S. Lavrijssen-Heijmans, L. Hancher, op. cit., s. 15. 
nowelizację ram regulacyjnych łączności elektronicznej24, której projekt zaprezentowała we wrześniu 2016 roku $^{25}$. Projekt ten wydaje się jednym z ambitniejszych w ramach strategii Jednolitego Rynku Cyfrowego — jest zbiorem inicjatyw ustawodawczych i nieustawodawczych mających na celu dokonanie przeglądu ram regulacyjnych w obszarze telekomunikacji wraz z modernizacją przepisów telekomunikacyjnych, aktualizowanych poprzednio w 2009 roku przy okazji tworzenia BEREC.

Nowe przepisy zostały przedstawione w formie jednej dyrektywy - ustanawiającej Europejski kodeks komunikacji elektronicznej ${ }^{26}$, niemniej towarzyszy im również pakiet dodatkowych dokumentów. Co prawda ostatnie lata w sektorze komunikacji elektronicznej UE, wskutek opisanych wcześniej zmian, to większa konkurencja, niższe ceny oraz większe możliwości dla przedsiębiorców i konsumentów, którzy - co trzeba jednak przyznać - w dalszym ciągu negatywnie odczuwają rozdrobnienie rynków łączności elektronicznej w zakresie tworzenia jednolitego rynku telekomunikacyjnego. Celem przygotowywanej nowelizacji jest wprowadzanie dalszych zmian we wszystkich głównych obszarach regulacji, pozwalających na zapewnienie jeszcze skuteczniejszych i bardziej spójnych instytucjonalnych ram dla regulacji sektora łączności elektronicznej. Powinno to nastąpić głównie przez dostosowanie przepisów telekomunikacyjnych do pojawiających się potrzeb jednolitego rynku cyfrowego, a wyrażać się między innymi w lepszym dostępie do infrastruktury, budowie i lepszym wykorzystaniu sieci łączności o bardzo dużej przepustowości, usłudze powszechnej, skoordynowaniu zarządzania widmem radiowym dla sieci bezprzewodowych, tworzeniu równych warunków funkcjonowania dla zaawansowanych sieci cyfrowych i usług innowacyjnych oraz jednolitym zdefiniowaniu usług łączności elektronicznej27. Proponowane zmiany zapewnią tym samym większą konkurencyjność i przewidywalność inwestycji, lepsze wykorzystanie częstotliwości radiowych oraz skuteczniejszą ochronę konsumentów w obszarach, w których ogólne przepisy dotyczące ochrony konsumentów nie uwzględniają potrzeb charakterystycznych dla sektora telekomunikacyjnego, a także bezpieczniejszy dostęp do Internetu i sprawiedliwsze zasady funkcjonowania rynku telekomunikacyjnego dla wszystkich jego uczestników.

${ }^{24}$ COM (2015) 192 final.

25 Wniosek z dnia 14 września 2016 roku dotyczący rozporządzenia Parlamentu Europejskiego i Rady ustanawiającego Organ Europejskich Regulatorów Łączności Elektronicznej \{COM (2016) 591 final - 2016/0286 (COD)\}.

26 Wniosek z dnia 12 października 2016 roku dotyczący dyrektywy Parlamentu Europejskiego i Rady ustanawiającego Europejski kodeks łączności elektronicznej \{COM (2016) 590 final 2016/0288 (COD)\}.

27 Por. Communication from the Commission to the European Parliament, the Council, the European Economic and Social Committee and the Committee of the Regions: „Connectivity for a Competitive Digital Single Market — Towards a European Gigabit Society” \{COM (2016) 587 final $\}$. 
W celu zapewnienia spójnego i przewidywalnego stosowania przepisów na całym jednolitym rynku cyfrowym Komisja zaproponowała także pewne zmiany instytucjonalne w sektorze łączności elektronicznej. W tym kontekście uznała, że projektowane zmiany na rynku i w otoczeniu technologicznym spowodują konieczność wzmocnienia ram instytucjonalnych poprzez zwiększenie roli BEREC. Krokiem w tym kierunku ma być ustanowienie BEREC jako pełnoprawnej zdecentralizowanej agencji UE, przy jednoczesnym pozostawieniu dotychczasowej niezależności KOR w każdym kraju członkowskim ${ }^{28}$. Należy przypomnieć, że obecna hybrydowa struktura BEREC obejmuje organ o charakterze międzyrządowym, skupiającym KOR, wykonujące zharmonizowane unijne zadania regulacyjne, który wspierany jest przez Urząd BEREC — niewielką agencję wspólnotową świadczącą usługi wsparcia zawodowego i administracyjnego dla BEREC.

W ramach trwającej dyskusji głos zabrał Parlament Europejski, który w swojej rezolucji ${ }^{29}$ poparł Komisję we wprowadzaniu sprawniejszych ram instytucjonalnych w sektorze telekomunikacyjnym. W opinii Parlamentu należy wzmocnić rolę, zdolności i uprawnienia decyzyjne BEREC, aby umożliwić mu wspieranie spójnego stosowania ram regulacyjnych łączności elektronicznej, zapewnić skuteczny nadzór nad rozwojem jednolitego rynku sprawowany przez BEREC oraz pomóc w rozwiązywaniu przez BEREC sporów transgranicznych, czego podstawą powinno być lepsze wyposażenie finansowe i osobowe BEREC oraz odpowiednie wzmocnienie jego struktury zarządzania. W opinii Parlamentu dzieje się to co prawda od momentu powstania BEREC i Urzędu BEREC, albowiem sukcesywnie postępuje spójne wdrażanie ram regulacyjnych, KOR i instytucje UE mogą liczyć na jego cenne doradztwo techniczne, a także powstaje wiele wytycznych dotyczących realizacji obowiązków KOR, jak też opinie w sprawie projektów aktów wykonawczych, przyjmowanych następnie przez Komisję, jednak BEREC i Urząd BEREC powinny odgrywać znacznie większą rolę w dziedzinie łączności elektronicznej, poprzez powierzenie im dodatkowych zadań, co w lepszym stopniu zapewniałoby spójne wdrażanie ram regulacyjnych i pobudzało rozwój rynku łączności elektronicznej w całej UE. BEREC mógłby wówczas lepiej działać w interesie obywateli UE. Zdaniem Parlamentu drogą do osiągnięcia tych celów jest właśnie wzmocnienie instytucjonalnej roli oraz struktury zarządzania BEREC poprzez przekształcenie go $\mathrm{w}$ agencję unijną. Ta idea zmiany struktury, zarządzania, funkcjonowania, programowania i odpowiedzialności BEREC jest zresztą spójna ze wspólnym oświadczeniem Parlamentu Europejskiego, Rady Europejskiej i Komisji w sprawie agencji zdecentralizowanych z dnia 19 lipca 2012 roku („wspólne podejście”).

Połączenie BEREC i Urzędu BEREC w pełnoprawną agencję unijną, z zachowaniem jednak dobrze znanej nazwy BEREC, wiązałoby się z przyznaniem

28 Szerzej zob. K. Rokita, Niezależność krajowych organów regulacyjnych oraz krajowych organów konkurencji w świetle prawa Unii Europejskiej, Wrocław 2017, s. 340 n.

29 Rezolucja Parlamentu Europejskiego z dnia 19 stycznia 2016 roku w sprawie „W kierunku aktu o jednolitym rynku cyfrowym" $\{2015 / 2147$ (INI) $\}$. 
nowej agencji szerszego mandatu niż ma obecnie BEREC oraz nałożeniem na nią nowych zadań, co z kolei spowodowałoby jej mocniejszą pozycję w całym mechanizmie rynkowych środków regulacyjnych. Nowa agencja powinna jednak kontynuować prace BEREC, w dalszym ciągu współpracując z KOR, gromadząc od nich wiedzę fachową, którą dysponują, z jednoczesnym ujednoliceniem niektórych ich zadań i kompetencji jako filarów nowej struktury instytucjonalnej. Zdaniem projektodawców nie doprowadzi to do zmniejszenia niezależności politycznej KOR, a wręcz przeciwnie — pozwoli rozszerzyć ochronę przed wpływami z zewnątrz na wszystkie nowe dziedziny kompetencji. Zadaniem KOR w dalszym ciągu będzie radzenie sobie z niedoskonałościami rynków krajowych z zastosowaniem odpowiednich środków naprawczych oraz zapewnianie, aby regulacje te przyczyniały się do realizacji wspólnych celów politycznych. Dostałyby one także dodatkowe narzędzia służące rozwiązywaniu obecnych problemów związanych z łącznością, które stosowane byłyby w zależności od krajowych uwarunkowań, których ocena należałaby właśnie do zadań KOR.

Propozycja likwidacji obecnej struktury BEREC i utworzenia pełnoprawnej agencji UE budzi jednak również spore kontrowersje ${ }^{30}$. Powstaje wszakże uzasadniona obawa co do zachowania dotychczasowego poziomu niezależności KOR, zarówno od graczy rynkowych, jak i innych źródeł interwencji zewnętrznej lub nacisków politycznych ${ }^{31}$. KOR powinno się wszakże wyraźnie zagwarantować niezależność, w tym w zakresie wdrażania przysługującego im budżetu oraz minimalnego zestawu ich podstawowych kompetencji na rynkach krajowych, także w zakresie egzekwowania regulacji poprzez stosowanie proporcjonalnych sankcji w formie kar i nakazów (bez konieczności uciekania się do sądów krajowych), co jednoznacznie nie wynika z projektowanych zmian regulacyjnych. Twierdzi się przy tym, że obecnie KOR z dużym powodzeniem zapewniają spójność podejścia regulacyjnego na swoich rynkach krajowych, a przez dysponowanie takim samym zestawem kompetencji w każdym kraju członkowskim umożliwiają BEREC realizowanie spójnych inicjatyw harmonizacyjnych. Skoro BEREC, oprócz zbierania wspólnych doświadczeń KOR w celu tworzenia i konwergencji praktyk regulacyjnych, odgrywa ważną rolę doradczą dla instytucji europejskich, wątpliwości w projekcie dyrektywy musi budzić także proponowane uzależnienie BEREC od Komisji, które przejawia się przez jej rolę w wyborze dyrektora wykonawczego BEREC (osoba spoza KOR), który byłby przedstawicielem prawnym tworzonej agencji, zamiast samego przewodniczącego BEREC (będącego jednocześnie urzędującym szefem jednego z KOR), który dodatkowo miałby przejąć niektóre kompetencje członków BEREC. Podważeniem niezależności agencji BEREC jest też propozycja, aby stały personel agencji, zamiast ekspertów KOR, przewodniczył eksperckim grupom roboczym

30 Szerzej zob. projekt ogólnej opinii Organu Europejskich Regulatorów Łączności Elektronicznej (BEREC) w sprawie propozycji Komisji Europejskiej dotyczących przeglądu ram regulacyjnych łączności elektronicznej \{BoR (16) 213\}.

31 K. Rokita, op. cit., s. 155 n. 
agencji BEREC. Te założenia mogą potencjalnie naruszyć niezależność BEREC w stosunku do Komisji, podważając podstawowe założenie propozycji zmian deklarujące przecież zwiększenie niezależności KOR, a w rzeczywistości ograniczające dostęp do praktycznej wiedzy i zredukowania ich niezależności.

Podkreśla się w tym kontekście również, że przekształcenie BEREC w agencję UE osłabi jego główną zaletę i wyróżniającą cechę, a mianowicie zakorzenienie w KOR tworzących BEREC ${ }^{32}$. Planowane zmiany wykluczają bowiem właściwie KOR z zarządzania agencją, ale i z możliwości rzeczywistej pracy w jej ramach, skoro planuje się wymianę przewodniczących eksperckich grup roboczych BEREC z ekspertów KOR na personel agencji. A to może paradoksalnie spowalniać, a nie przyspieszać tempo współpracy KOR oraz rozwój i rozpowszechnianie zharmonizowanych najlepszych praktyk, a w ślad za tym dążenie do jednolitego rynku. W projekcie widać także tendencję do stworzenia przerośniętej, kosztownej i biurokratycznej struktury, która z całą pewnością nie zwiększy efektywności BEREC i nie zredukuje nadmiernego ciężaru zadań administracyjnych i biurokratycznych. Koszty nowo proponowanego kształtu BEREC będą znaczące, gdyż obejmą wzrost liczby stałych pracowników Urzędu BEREC, a co za tym idzie spory wzrost kosztów unijnej regulacji w telekomunikacji.

W swoim stanowisku BEREC podkreśla ponadto, że tak naprawdę nie zostały podane przez Komisję i Parlament istotne powody do przekształcania BEREC w zdecentralizowaną agencję UE. W rzeczywistości bowiem model zdecentralizowanej agencji UE jest stosowany głównie do delegowania zadań wspólnotowych z Komisji, celem zaś BEREC jest łączenie i rozwój krajowej regulacyjnej wiedzy specjalistycznej oraz udzielanie porad instytucjom UE. Obecnie nie ma funkcji w ramach Komisji, która powinna być w sposób uzasadniony przekazana do BEREC, a tym samym uzasadnienia stosowania wspólnego podejścia i utworzenia unijnej agencji. Kilka zaś wiążących uprawnień, jakie proponuje się powierzyć BEREC, na których Komisja opiera swoją argumentację konieczności przekształcenia BEREC $\mathrm{w}$ agencję UE, nie ma właściwego uzasadnienia, co czyni niejasnym cel, jakiemu ma ono służyć. Wiele z proponowanych zadań to bowiem nic więcej jak tworzenie niepotrzebnych obciążeń administracyjnych dla przedsiębiorstw i KOR, jak choćby proponowany proces zgłaszania zezwoleń ogólnych. Nowe uprawnienia do podejmowania wiążących decyzji niekoniecznie zatem wymagają przekształcania BEREC w agencję $\mathrm{UE}^{33}$.

Wydaje się, że dokonując zmian instytucjonalnych w sektorze łączności elektronicznej, w żadnym wypadku nie powinno się obecnie tak bardzo centralizować uprawnień decyzyjnych na poziomie unijnym, aby marginalizować działalność KOR. Centralizacja kompetencji regulacyjnych na poziomie europejskim byłaby

32 Projekt ogólnej opinii Organu Europejskich Regulatorów Łączności Elektronicznej (BEREC) w sprawie propozycji Komisji Europejskiej..., s. 15 n.

33 Przykładem może być niedawno utworzona Europejska Rada Ochrony Danych (EDPB), która ma wiążące uprawnienia decyzyjne i nie jest agencją UE. 
korzystna z wielu względów. Mogłaby być bardzo pomocna choćby w zwalczaniu tak zwanych bezpośrednich skutków zewnętrznych i przy podejmowaniu decyzji w różnych państwach członkowskich w wypadku usług regulowanych świadczonych na poziomie międzynarodowym oraz przyczyniałaby się do oszczędności na kosztach informacji i transakcji po stronie inwestora, skoro we wszystkich jurysdykcjach obowiązywałyby te same istotne zasady regulacyjne, wydaje się także bardziej skuteczna niż zdecentralizowane działania prowadzone przez wiele różnych organów regulacyjnych, wówczas gdy dany obszar podlega regulacyjnemu efektowi skali ${ }^{34}$. Zdaje się też, że centralizacja uprawnień, odległa od wszelkich krajowych grup interesów (dominujących przedsiębiorstw i jednostek z nimi powiązanych), utrudniałaby także praktykę przejmowania organów regulacyjnych przez działające jedynie we własnym interesie dobrze zorganizowane strony, szczególnie gdy KOR w jakimś kraju członkowskim jest stosunkowo słaby i podatny na naciski ze strony uczestników rynku ${ }^{35}$.

Centralizacja uprawnień regulacyjnych może budzić jednak znacznie więcej poważnych wątpliwości, niż przynosić korzyści. Chodzi tu zwłaszcza o konieczność posiadania przez organ centralny specjalistycznej wiedzy o 27 rynkach krajowych, którą mają tylko osoby będące członkami $\mathrm{KOR}^{36}$, utrudnienia $\mathrm{w}$ podejmowaniu decyzji z uwagi na istnienie znaczących różnic $\mathrm{w}$ preferencjach obywateli poszczególnych krajów członkowskich oraz dysproporcji w poziomie rozwoju infrastruktury łączności elektronicznej, prawdopodobieństwo występowania problemów pomiędzy stronami, w tym związanych z komunikacją stron, dalekość rynku i mniej bezpośrednie odczuwanie skutków decyzji regulacyjnych przez uczestników rynku, ograniczanie konkurencji w stosowaniu rozwiązań regulacyjnych pomiędzy poszczególnymi KOR, która sprzyja wypracowywaniu najskuteczniejszych rozwiązań regulacyjnych w omawianym sektorze, a ponadto o wątpliwości co do zgodności z konstytucyjnymi zasadami UE, takimi jak zasada pomocniczości i proporcjonalności (art. $5 \mathrm{WE})^{37}$.

34 Zob. J.E. Stiglitz, Economics of the Public Sector, New York 1988, s. 72, 185-189; D. Geradin, N. Petit, op. cit.

35 D.J. Neven, L.H. Röller, The allocation of jurisdiction in international antitrust, „,European Economic Review" 44, 2000, s. 845, 847-848.

36 Projekt rozporządzenia Parlamentu Europejskiego i Rady ustanawiającego Europejski Urząd ds. Rynków Łączności Elektronicznej \{COM (2007) 699, pkt 3.1 uzasadnienia\}.

37 Zob. D. Geradin, N. Petit, op. cit., s. 11; Dokument roboczy służb Komisji - Ocena wpływu - Dokument towarzyszący do projektu dyrektywy Parlamentu Europejskiego i Rady zmieniającej dyrektywy Parlamentu Europejskiego i Rady 2002/19/ WE, 2002/20/WE i 202/21/WE — Dokument towarzyszący do projektu dyrektywy Parlamentu Europejskiego i Rady zmieniającej dyrektywy Parlamentu Europejskiego i Rady 2002/22/WE i 2002/58/WE — Dokument towarzyszący do projektu rozporządzenia Parlamentu Europejskiego i Rady ustanawiającego Europejski Urząd ds. Rynków Łączności Elektronicznej \{COM (2007) 697, pkt 7.5\}. 


\section{WNIOSKI}

U podstaw instytucjonalnej przebudowy sektora łączności elektronicznej w przeszłości leżało wiele względów, z których najważniejsze to poprawa niedociągnięć i zespojenie realizacji obowiązujących ram regulacyjnych w krajach członkowskich. Wydaje się, że obecna struktura instytucjonalna omawianego sektora, silnie wspierana do tej pory przez Komisję i Parlament Europejski, jest rozważnym kompromisem właściwie łączącym konkurujące wartości reprezentowane przez poszczególne podejścia. $Z$ jednej strony, utrzymując kompetencje KOR, zachowuje on autonomię instytucjonalną krajów członkowskich, co jest zgodne z zasadami pomocniczości i proporcjonalności, uwzględnia specyfikę poszczególnych krajów i umożliwia (przynajmniej w pewnym stopniu) dalsze eksperymentowanie $\mathrm{w}$ zakresie regulacji. $\mathrm{Z}$ drugiej strony, poprzez przeniesienie niektórych kompetencji na szczebel europejski, w szczególności w dziedzinie środków nakładanych na wyznaczone przedsiębiorstwa, umożliwia bardziej spójne wdrożenie ram regulacyjnych w krajach członkowskich i zapobiega rozprzestrzenianiu się bezpośrednich skutków zewnętrznych na terenie UE. I właśnie poprawie spójności ram regulacyjnych w UE pomaga powołany BEREC, organ regulacyjny będący zdecentralizowaną siecią krajowych organów regulacyjnych, któremu nadane zostały pewne kompetencje w ramach regulacji w sektorze telekomunikacyjnym i łączności elektronicznej.

Utworzenie BEREC należy uznać za dobre posunięcie, a dotychczasową jego działalność ocenić pozytywnie. Okazuje się on skuteczniejszym narzędziem regulacyjnym niż istniejące $\mathrm{w}$ przeszłości ERG, ponieważ stanowi niezależną i sformalizowaną strukturę posiadającą organy, budżet, personel oraz jasno zdefiniowane kompetencje. Przez to dużo skuteczniej przyczynia się do stworzenia wewnętrznego rynku łączności elektronicznej. Pozytywnym skutkiem utworzenia takiego ciała jest także uwolnienie istniejących kwestii technicznych od nacisków politycznych, co zapewnia spójność polityki w czasie (w sektorach zależnych od sieci zastępuje to niekorzystne działanie krajowych organów regulacyjnych), a ponadto odciąża inne instytucje europejskie, które dzięki temu mogą skupiać się na swoich podstawowych zadaniach strategicznych (czyli tworzeniu polityk). Wskutek powołania BEREC doszło do jasnego rozdzielenia kompetencji (obowiązki polityczne i strategiczne dla Komisji a zadania techniczne dla BEREC), co przyczynia się do lepszego rozumienia Europy przez jej obywateli ${ }^{38}$.

Obecna próba wprowadzania zmian w zakresie kompetencji KOR oraz BEREC, które miałyby na celu zapewnienie jeszcze bardziej spójnego stosowania przepisów dotyczących łączności elektronicznej na jednolitym rynku cyfrowym, niewątpliwie wzmacnia BEREC jako nową agencję unijną, przez co następuje jednoczesne zmniej-

38 A. de Streel, The current and future European regulation of electronic communications: A critical assessment, „Telecommunications Policy” 32, 2008, s. 722, 732. 
szenie faktycznych kompetencji KOR (na rzecz BEREC). Wydaje się, że zasadność tych zmian wymaga jednak dokonania dalszych, pogłębionych analiz w kierunku jednoznacznego uznania, że przyniosą one zakładane korzyści w sektorze telekomunikacyjnym. Obecna struktura instytucjonalna zapewniająca KOR i państwom członkowskim wysoki stopień elastyczności pozwala dostosowywać regulacje do specyficznych okoliczności krajowych lub lokalnych, jednak większa centralizacja i spójność regulacyjna leżałaby we wspólnym europejskim interesie.

\title{
BODY OF EUROPEAN REGULATORS FOR ELECTRONIC COMMUNICATIONS AS A CENTRALISED NETWORK OF NATIONAL REGULATORY BODIES. SELECTED ASPECTS OF INSTITUTIONAL ORDER IN THE ELECTRONIC COMMUNICATIONS SECTOR
}

\author{
Summary
}

The basic tasks of The Body of European Regulators for Electronic Communications (BEREC) are related to advising EU institutions and the regulatory bodies of EU member states on issues regarding the application of the EU regulatory electronic communications framework. Through its operations, BEREC supports the guarantee of fair competition and regulatory cohesion on the internal market in the area of electronic communications. At present, BEREC enjoys the status of an independent regulatory body, gathering decision-making national regulatory bodies within its structures and drawing from their expertise and regulatory experience. The paper discusses the rules governing the set-up and activity of the Body of European Regulators for Electronic Communications in the context of consistency of the regulations governing its activity with the principles of good governance. Furthermore, the paper addresses the planned comprehensive reform of regulations in the telecoms sector, which was presented by the European Commission as a particularly ambitious project under the Single Digital Market strategy. The paper was written in the framework of research of the research programme of the National Centre of Science financed on the basis of the decision no. DEC-2013/08/A/HS5/00642.

Keywords: Body of European Regulators for Electronic Communications, the electronic communications sector, the Electronic Communications Office, regulation of infrastructural sectors

\section{BIBLIOGRAFIA}

Chiti E., The emergence of a community administration: The case of European agencies, „Common Market Law Review" 37, 2000.

Everson M., Independent agencies: Hierarchy beaters?, „European Law Journal” 2, 1995.

Geradin D., Petit N., The development of agencies at EU and national levels: Conceptual analysis and proposals for reform, „Working Paper Series” 2004, http://ssrn.com/abstract=489722.

Good Governance in Europe's Integrated Market, red. C. Joerges, R. Dehousse, Oxford 2002.

Kamiński F., Nowelizacja pakietu regulacyjnego dla rynku komunikacji elektronicznej Unii Europejskiej - Organ Europejskich Regulatorów Łączności Elektronicznej, „Biuletyn Informacyjny Instytutu Łączności” 2009, nr 1. 
Lang J.T., The duties of cooperation of national authorities and courts under Article 10 E.C.: Two more reflections, „European Law Review” 26, 2001.

Lavrijssen-Heijmans S., Hancher L., European regulators in the network sectors: Revolution or evolution?, „TILEC Discussion Paper” 24, 2008.

Majone G., The agency model: The growth of regulation and regulatory institutions in the European Union, „EIPASCOPE” 6, 1997.

Nenova M.B., EC Electronic Communications and Competition Law, London 2007.

Neven D.J., Röller L.H., The allocation of jurisdiction in international antitrust, „European Economic Review" 44, 2000.

Parlament jako instytucjonalny uczestnik sektorów sieciowych, red. M. Szydło, W. Szydło, Wrocław 2014.

Rokita K., Niezależność krajowych organów regulacyjnych oraz krajowych organów konkurencji w świetle prawa Unii Europejskiej, Wrocław 2017.

Stiglitz J.E., Economics of the Public Sector, New York 1988.

Streel A. De, The current and future European regulation of electronic communications: A critical assessment, „Telecommunications Policy” 32, 2008.

Szydło M., Krajowy parlament jako regulator sektorów sieciowych, Warszawa 2013.

Szydło M., Prawo konkurencji a regulacja sektorowa, Warszawa 2010.

Vos E., Reforming the European Commission: What role to play for EU agencies?, „Common Market Law Review" 37, 2000.

Yataganas X.A., Delegation of regulatory authority in the European Union - The relevance of the American model of independent agencies, „Jean Monnet Working Paper” 3, 2001, nr 1. 